\title{
The Use of 3M Technique With Three Dimensional Media in Teaching Writing Explanation Text to Students Of Vocational School
}

\author{
Teti Sobari ${ }^{1}$, Nanin Nurohmi ${ }^{2}$ \\ \{tetisobari@ikipsiliwangi.ac.id ${ }^{1}$, naninnurohmi@gmail.com² ${ }^{2}$ \\ IKIP Siliwangi, Bandung, Indonesia
}

\begin{abstract}
This research is aimed to find out the process of learning to write using $3 \mathrm{M}$ techniques with three-dimensional media, the students' ability in writing explanatory texts, and the students' activities in learning to write explanatory text using $3 \mathrm{M}$ techniques with three-dimensional media. The population of this research is students of vocational school majoring in Computer Network Engineering totaling 31 people. This study uses a classroom action research method with two cycles. Each cycle consists of plan, act, observe and reflect. The research shows that the learning process of writing explanatory text using $3 \mathrm{M}$ techniques with three-dimensional media run well. The ability of students to write the explanatory text has increased from an average score of 65.03 in the first cycle to 66.61 in the second cycle with a good category. Students are quite active in learning to write explanatory text using $3 \mathrm{M}$ techniques with three-dimensional media.
\end{abstract}

Keywords: Explanatory Text, 3M Technique, Three-Dimensional Media

\section{Introduction}

Indonesian Language subject is one of the compulsory subjects at all levels of education. This is in line with the opinion of Salam [1] that subjects constitute a unified subject matter that is written systematically so that it supports the atmosphere for students to learn. Indonesian Language learning has several problems related to student learning activities and enhancing student abilities. Student activity in learning is determined by the existence of a synergic relationship between the teacher and students in creating a learning process that can increase learning passion in order to influence students' abilities. In connection with that, [2] said that students and teachers play an active role in processing messages, information, or subject matter so that harmonious relationships are established to obtain meaningful learning. The teacher tries to create learning conditions that allow the learning experience to occur by mobilizing all learning resources and using appropriate teaching and learning strategies. Students with all their characteristics try to develop themselves through various learning activities to achieve maximum learning outcomes.

Indonesian language learning in the 2013 curriculum is based on the text genre. Learning activities refer to analyzing and producing various types of text. Likewise in writing learning in a 2013 text-based curriculum that aims for students to gain hands-on experience in expressing their ideas and thoughts into written form. The domain of writing learning is based on the text genre so that students have the ability to compose their writing based on a structured mindset. 
This means that text-based learning will imply indirectly to sharpen students' ability to write text critically and structurally and be able to be applied in daily activities in their lives. This is in line with the opinion of Akhadiah [3] that writing is important because by writing the authors will know the potential of themselves and can develop ideas and opinions and broaden their insight.

Writing activities require the authors' ability to understand the mechanical aspects in developing their writing. This is supported by Sobari [2] that writing involves aspects of reasoning and aspects of logic that are reflected in the content and composition of the writing, as well as linguistic aspects that are reflected in the use of words, sentences, and writing mechanics. This is in line with Sirait [4] that an author must at least master five components of writing, namely: 1) content (material); 2) writing organization; 3) linguistic (written language rules); 4) writing style; and 5) writing mechanism.

The 2013 curriculum is based on scientific, competence, character, and text genres. Text In the 2013 curriculum is not interpreted as a form of written language but as a complete expression of the human mind which includes the situation and context [5]. The text genre in the 2013 curriculum includes explanatory text. The explanatory text is a text that contains information about a matter in order to inform the reader of natural facts or events. Sari and Rusmianto [6] argue that explanatory text is a genre of text that presents a logical relationship of several events. Likewise, Mahsun [7] said that the explanatory text is a text that explained natural and social phenomena. The structure of the explanatory text is general statements, explanatory lines, and interpretations. The explanatory text in student books is text relating to natural events, including texts about tsunamis and earthquakes. Complex explanatory text according to Kosasih [8] is text that explains the process of the phenomenon that occurs, whether it is related to nature, culture or society. The complex explanatory text structure consists of three parts according to Amalia [9] that are: (1) The general statement contains general statements about a topic, which will explain the process of its existence, the process of its occurrence, and the process of forming concisely, interestingly and clearly that arouse the interest of readers. (2) Explanation series containing details of the explanation of the process of existence, the process of occurrence of which the explanation is gradual. (3) Concluding remarks containing conclusions or statements about the topic or process described.

The explanatory text contains the structure and linguistic characteristics. Kosasih [8] stated, The explanatory text uses many facts or contains statements that have causal relationships. Based on the statement the linguistic characteristics contained in the explanatory text are the causal relationship and factual statements. From Kosasih's statement, it can be concluded that students must use facts or statements that have a causal relationship when producing explanatory texts. Statement of cause and effect relationships including the use of time conjunctions and causal conjunctions.

Indonesian language learning at the vocational school level requires a technique that can foster the spirit of learning. The technique chosen should be able to help students understand the concept and improve the ability to write explanatory text. Using the right techniques is expected to create fun learning. To achieve all this, this research uses $3 \mathrm{M}$ techniques through the use of three-dimensional media.

$3 \mathrm{M}$ technique refers to the learning principles proposed by Ki Hadjar Dewantara, namely Niteni, Nirokke, Nambahi [10]. Mardjuki in Harefa [11] states that 3M technique or imitatingprocessing-developing is a technique that can facilitate writing learning, whether it is learning to compose poetry, short stories, novels, articles, or books. This technique enables the writer as an observer of similar writing circulating in the community. For example in writing short stories, an author can observe other writers' short stories that have been made. [12] 
Indonesian language learning based on the 2013 curriculum requires creative teachers and students to create an attractive learning process in order to foster students' interest in learning. In this study, the author uses three-dimensional learning media in the form of natural events or phenomena that are made directly by students in three-dimensional form. Three-dimensional media is an interactive learning tool that has length, height, and volume. Daryanto [13] argues that three-dimensional media are without projections in the form of real or similar to original objects. The three-dimensional media can help students direct their imagination towards the phenomena to be written.

Three-dimensional media is made in such a way that it can resemble natural, social and environmental events or phenomena. The creation of three-dimensional media requires the skills of teachers and students in packaging them using materials that are simple and easy to obtain. In this study, students are required to create three-dimensional media about natural, social and environmental phenomena.

Based on the background above, the authors are interested in researching the learning of explanatory text writing using $3 \mathrm{M}$ techniques with three-dimensional media. The purpose of this study is to describe students activities in writing learning using $3 \mathrm{M}$ techniques and describe students' ability to write explanatory text through $3 \mathrm{M}$ techniques using three-dimensional media.

\section{Method}

This research is a classroom action research consisting of two cycles. The focus of this research is to take action on classroom learning by observing the activities of students and teacher. Each cycle consists of four activities which include plan, act, observe and reflect activities. The sample of the research was students of class XI of SMK Kartika XIX-1 in Bandung City which amounted to 31 students.

The classroom action research model used in this study is developed by Stephen Kemmis and Robbin McTaggart. The model consists of a cycle that includes four components, namely planning, acting, observing, and reflecting. After one cycle has been implemented, especially after reflection, the stage is followed by re-planning/revision of the next implementation. Replanning is carried out in the form of a separate cycle [12]

The data collected are data of learning activity and data of explanatory text writing skills of students from cycle I and cycle II. Data collection of student activity is done by observation technique conducted by subject teachers using observation instruments. While the data of explanatory text writing skills is carried out through an explanatory text writing test conducted at the end of the first cycle and second cycle.

This research was carried out for three months, starting on odd semester 2018-2019 in JulySeptember 2018 which included planning, acting, observing, and reflecting activities. The assessment aspects of explanatory text writing skills include text structure, language features, and text characteristics

\section{Result and Discussion}

This section will discuss the results of tests and non-tests which consist of pre-cycle, a cycle I, and cycle II about explanatory text writing skills after an action or learning was carried out using $3 \mathrm{M}$ techniques through three-dimensional media. 


\subsection{Pre-Cycle}

Pre-cycle is carried out before learning to write explanatory text is implemented. The results of the pre-cycle data are obtained that the ability of students to write explanatory is still relatively lacking, as shown in table 1. Explanatory text from 31 students who took the test showing an average of 53.38. Aspects assessed in writing explanatory texts include: the structure of the text, the language features of the text, and the characteristics of the explanatory text

Table 1 Results of Explanatory Text Writing Ability of Pre-cycle

\begin{tabular}{lcllll}
\hline Category & Interval & Frequency & Score & \% & Description \\
\hline Low & $0-54$ & 21 & 1101 & 66.53 & $1655 / 31=53.38$ \\
Fair & $55-64$ & 10 & 554 & 33.47 & Low Category \\
Good & $65-79$ & - & & & \\
Satisfactory & $80-100$ & - & 1655 & 100 & \\
\hline
\end{tabular}

Table 1 data shows that the average pre-cycle value of the ability to write explanatory text is 53.38. Thus the ability of students of class XI to write explanatory texts is still not good. There are 21 students in low category $(66.53 \%)$ and in the fair category is 10 students $(33.47 \%)$.

Table 2 Results of Every Aspect of Explanatory Text Writing Ability in Pre-Cycle

\begin{tabular}{lll}
\hline \multicolumn{1}{c}{ Aspect of Assessment } & \multicolumn{1}{c}{ Mean } & \multicolumn{1}{c}{ Percentage } \\
\hline Structure & 22.35 & 41.90 \\
Language features & 14.32 & 26.83 \\
Text characteristics & 16.70 & 31.27 \\
Total & 53.38 & 100 \\
\hline
\end{tabular}

Based on table 2 the lowest result is in the aspect of language features with a percentage of $26.83 \%$. While the ability to determine the structure is $41.90 \%$ and text characteristics are $31.27 \%$.

\subsection{Cycle 1}

In the first cycle, two meetings were held. The first meeting was to identify information in the explanatory text with the following learning details.

Plan

Preparation carried out in cycle 1 is by preparing a lesson plan, syllabus, media, and teaching materials.

Act

In the first cycle, two meetings were held. The first meeting was to identify information in the explanatory text with the following learning details

First Meeting

The first meeting was held on the 5th session or started at 10.15-11.50 with the details of the activity: the teacher checked the attendance of all students, then conveyed the learning objectives, and then brainstormed the students about the subject matter at the previous meeting about the procedure text.

The teacher explained the explanatory text, all the students listened to the teacher's explanation. Next, the teacher shared sample texts for individual students to analyze their structure. In the act of analyzing the structure of the explanatory text, most students did not 
understand what to do and they always asked the teacher about their assignments. The time provided to analyze was around 40 minutes. Within 10 minutes the paperwork was still empty. Only 3 students tried to answer and fill in the paperwork. After 30 minutes almost all students had analyzed the explanatory text based on the structure. Until the exercise time ran out there were still around 7 students did not do the exercise. The next activity the teacher and students discussed analyzing the structure of the explanatory text that had been done by students. The teacher asked about the structure of the explanatory text to 5 students randomly. The answers of the five students varied. Student E answered that the text structure included opening, content, and closing. Whereas student A answered that the structure of the explanatory text included general statements, explanatory series, and conclusions. After that, the teacher explained the correct structure of the explanatory text, namely the general statement, the explanatory series, and the closing.

The teacher and students made conclusions from the learning activities that had been carried out. The teacher gave the task to students to analyze the structure of the explanatory text. Then the teacher asked about the implementation of learning on that day. In the end, the teacher closed the learning activity.

\section{Second Meeting}

The second meeting was carried out on August 16, 2018, at 07.00-08.40 regarding the construction of information in the explanatory text with the following activities.

The teacher prepared the class by checking student attendance. Then she did apperception by asking about the tasks that had been given. Only a portion of students from 31 students who answered that they had worked on the task of analyzing the structure of the explanatory text. The works that had been done was collected to be corrected by the teacher.

At the second meeting, the teacher formed students into several groups. Each group consisted of 4-5 students and a total of 7 groups. The teacher provided a sample explanatory text that had been omitted in several parts and then students filled in some of the sections in groups. When observed, learning by grouping was not able to grow the participation of all group members. Members who actively participated were only one or two students, while the rest of the members just kept quiet and even did activities that were not related to learning activities. The teacher tried to remind them but this method was not so successful. At the end of the lesson, the teacher asked students to report the results of their group discussions. Groups 1 and 3 were the fastest groups to do the task then presented their work in front of the class. While other groups submitted their work at the end of the learning time.

Teacher and students made conclusions on learning that had been carried out. Next, the teacher asked about the reflection of the implementation of learning on that day.

\section{Observe}

First Meeting

At the first meeting, learning went smoothly, but there were still some obstacles, as follows (1) some students were still confused understanding material about the structure of explanatory text, (2) Most students did not focus on learning and talked a lot and played in class, (3) some students even did activities that were not related to learning, such as playing cellphones and sleeping, (4) there were students who could not answer questions about the structure delivered by the teacher verbally.

Second Meeting

At the second meeting, the learning went smoothly, but there were still some obstacles, as follows (1) most students had understood the explanatory text structure, (2) many students had not been active in group discussions, (3) There were still some students who chat and play games. 


\section{Reflect}

Based on the results of the implementation of learning in cycle I, it can be concluded that at the time of learning students had been able to understand the structure of the explanatory text but were still in a fair category that is $55.64 \%$ and $44.36 \%$ included the good category. Table 3 shows students' ability to understand the structure of the explanatory text in cycle I.

Table 3 Students' ability to write explanatory text in cycle I

\begin{tabular}{lccccl}
\hline \multicolumn{1}{c}{ Category } & Interval & Frequency & Score & $\%$ & \multicolumn{1}{c}{ Description } \\
\hline Low & $0-54$ & - & & & $1950 / 31=62.90$ \\
Fair & $55-64$ & 17 & 1085 & 55.64 & Fair Category \\
Good & $65-79$ & 14 & 865 & 44.36 & \\
Satisfactory & $80-100$ & - & 1950 & 100 & \\
\hline
\end{tabular}

The following table shows the ability to write an explanatory text based on assessment aspects.

Table 4 Students' ability to write explanatory text in each assessment aspect in cycle I

\begin{tabular}{lcc}
\hline \multicolumn{1}{c}{ Aspect of Assessment } & Mean & \% \\
\hline Structure & 25.90 & 39.83 \\
Language features & 18.48 & 28.42 \\
Text characteristics & 20.65 & 31.75 \\
Total & 65.03 & 100 \\
\hline
\end{tabular}

Based on table 4 above, it was known that students had understood the language features of the text (28.42\%) with the fair category, while the aspect of the text characteristics $(31.75 \%)$, and the linguistic text are quite good $(39.83 \%)$.

Based on the test results in cycle I, it is necessary to improve the learning, including (1) Appropriate techniques are needed so that all students are able to understand the material appropriately, and (2) the teacher needs to motivate students to focus more on learning and actively discussing.

\subsection{Cycle II}

In cycle II the learning material is about writing explanatory text with the details of learning as follows.

\section{Plan}

The implementation of learning in the second cycle was planned using the $3 \mathrm{M}$ technique, which includes imitating, processing, and developing. The teacher prepared learning tools including lesson plans, instruments, and learning media.

Act

First Meeting

In initiating the process of learning in cycle II, the teacher checked the attendance of students. The teacher delivered the learning objectives of writing explanatory text by taking into account the structure and language features of the explanatory text.

The teacher divided the class into 7 groups with each group consisting of 4-5 students. Each group was given an example of an explanatory text that the teacher displayed with a different theme. Group 1 paid attention to the "Merapi eruption phenomenon", group 2 about "floods", group 3 about "earthquake", group 4 about "solar eclipse", group 5 about "eclipse of the moon", group 6 about "brawl", and group 7 about "Football Supporters Riots". After viewing the 
program, each group member was required to make an explanatory text in turn. This meant that all students must continue and complete the explanatory text that the group had made. After all group members completed the explanatory text, they reread the text. Once text that had been compiled and read, each group member was given the opportunity to improve and develop the text.

In this discussion activity, almost all group members were able to play an active role in giving opinions about the content of the text. After finishing compiling the explanatory text, each group appointed one of its representatives to display the text in front of their friends. Other groups were allowed to provide input or criticism of texts made by other groups.

The teacher and students made conclusions from the learning activities that had been carried out. The teacher gave the task to students to create three-dimensional learning media that were related to the theme of the text that had been determined.

\section{Second Meeting}

In initiating the process of learning of the second meeting of cycle II, the teacher checked the attendance of students. The teacher delivered the learning objectives of writing explanatory text using $3 \mathrm{M}$ techniques assisted by three-dimensional media that students had created.

The teacher allowed students to form an existing group. Then each group appeared in front of the class to present the media theme they had made. Each group member made an explanatory text based on three-dimensional media created by each group.

Based on observations, the activities of group members were getting better. Almost all students paid attention to the media they had made to be the basis for writing explanatory text. The role of the teacher was only to direct and give motivation to students when there were students who had difficulty developing their writing.

The teacher and students concluded the learning activities that had been carried out. The teacher asked students about the learning atmosphere that day. All students expressed pleasure and easily made explanatory text with the help of the media they had made.

\section{Observe}

First Meeting

The results of observation at the first meeting of cycle II showed that students were able to make explanatory texts but there were still some problems, which were still limited in vocabulary mastery so that the development of explanatory texts was still low.

Second Meeting

At the second meeting of the cycle II, there were almost no significant obstacles. With the help of three-dimensional media, the atmosphere of learning was increasingly interesting. All students observed and understood the explanations of their group friends. All students were able to make explanatory text according to the three-dimensional media theme they made.

\section{Reflect}

Based on the results of the first and second meetings in cycle II, the results of learning showed significant improvement. This can be seen in the test results of the ability to write explanatory text as follows.

The following is a table 5 regarding students' ability to write explanatory text in cycle II.

Table 5 Students' ability to write explanatory text in cycle II

\begin{tabular}{llllll}
\hline Category & Interval & Frequency & Score & Percentage & Description \\
\hline
\end{tabular}




\begin{tabular}{lccccc}
\hline Low & $0-54$ & - & & & $2065 / 31=66.61$ \\
Fair & $55-64$ & 8 & 486 & 23.53 & Good Category \\
Good & $65-79$ & 23 & 1579 & 76.46 & \\
Satisfactory & $80-100$ & - & 1950 & 100 & \\
\hline
\end{tabular}

The following table 6 shows the ability to write an explanatory text based on assessment aspects.

Table 6 Students' ability to write explanatory text in each assessment aspect in cycle II

\begin{tabular}{lcc}
\hline \multicolumn{1}{c}{ Aspect of Assessment } & Mean & Percentage \\
\hline Structure & 26.29 & 39.47 \\
Language features & 19.06 & 28.63 \\
Text characteristics & 21.22 & 31.88 \\
Total & 66.61 & 100 \\
\hline
\end{tabular}

Based on table 6 above, students understood the language features of the text $(28.63 \%)$ with fair categories, while the text characteristics (31.88\%), and the text structure were good enough $(39.47 \%)$.

\subsection{Results}

Based on the results of the written test of pre-cycle, the cycle I, and cycle II, the following results were obtained.

Table 7 Mean recapitulation of the students' ability to write explanatory texts in each cycle

\begin{tabular}{lccl}
\hline \multicolumn{1}{c}{ Cycle } & Mean & Percentage & \multicolumn{1}{c}{ Description } \\
\hline Pre-cycle & 53.38 & 53.38 & Low \\
Cycle I & 65.03 & 65.03 & Fair \\
Cycle II & 66.61 & 66.61 & Good \\
\hline
\end{tabular}

Table 7 is the mean recapitulation of the students' ability to write explanatory text in each cycle which shows that there is an increase in the ability to write explanatory text starting from the pre-cycle (53.38), the cycle I (65.03), to cycle II (66.61). This means that $3 \mathrm{M}$ techniques using three-dimensional media are effectively used in learning explanatory text writing skills.

Table 8 Mean recapitulation of the ability to write explanatory text in each aspect of each cycle

\begin{tabular}{lccc}
\hline Aspect of Assessment & Pre Cycle & $\begin{array}{c}\text { Mean Per Cycle } \\
\text { Cycle I }\end{array}$ & Cycle II \\
\hline Structure & 22.35 & 25.90 & 26.29 \\
Language features & 14.32 & 18.48 & 19.06 \\
Text characteristics & 16.70 & 20.65 & 21.22 \\
Total & 53.38 & 65.03 & 66.61 \\
\hline
\end{tabular}

Table 8 shows that based on the aspect of assessment explanatory text writing skills from pre-cycle to cycle I increased by 11.65 (1.7\%) while from cycle I to cycle II increased by 1.58 $(0.2 \%)$. The data in table 8 shows that the highest aspect capability is the structure of the text (26.29) and the lowest aspect is language features (19.06).

\section{Conclusion}


Based on the description of the results of the study and the discussion above, it can be concluded that the ability of students of class XI to write explanatory text using $3 \mathrm{M}$ techniques through three-dimensional media has increased, from the mean score of the cycle I of 65.03 to 66.01 in cycle II. This shows that $3 \mathrm{M}$ technique with three-dimensional media is effective to improve explanatory text writing skills. Based on the three aspects assessed in the ability to write explanatory text, the best results obtained from the aspect of text structure reached $39.47 \%$ with the good category. Whereas the characteristic aspects of the explanatory text reached $31.88 \%$ with a good enough category. Student activity in cycle I was still low while in cycle II experienced an increase in student participation, especially in group activities and discussions.

\section{Reference}

[1] Istiqomah, "The Development of Learning Material: Explanation Text Based on Multimodal by Using Sway App in 11," Int. J. Educ. Res., vol. 4, no. 9, pp. 313-322, 2016.

[2] T. Sobari, "Penerapan teknik siklus belajar dalam pembelajaran menulis laporan ilmiah berbasis vokasional di smk," J. Semant., vol. 1, no. 1, pp. 17-41, 2012.

[3] S. Akhadiah, Pembinaan Kemampuan Menulis Bahasa Indonesia. Erlangga, 1991.

[4] B. Sirait, Bahan Pengajaran untuk Mata Kuliah Evaluasi Hasil Belajar Siswa. 1989.

[5] T. A. S. Warniatul Ulfah, "The Development of Teaching Materials of ExperienceBased Explanatory Text Writing on Class XI Students at SMA Negeri Unggul Aceh Timur," Br. J. English Linguist., vol. 5, no. 4, pp. 42-52, 2017.

[6] A. M. Sari and N. E. Rusmianto, "Jurnal Kata (Bahasa, Sastra, dan Pembelajarannya)," J. Kata (Bahasa, Sastra, dan Pembelajarannya), vol. 2, no. April, pp. 1-12, 2016.

[7] Janatun Naim; Nurlaksana Eko; Eka Sofia Agustina, "Jurnal Kata (Bahasa, Sastra, dan Pembelajarannya) Juni 2014,” J. Kata (Bahasa, Sastra, dan Pembelajarannya), vol. 2, no. 2, pp. 42-52, 2014.

[8] Kosasih, Jenis-Jenis Teks Analisis Fungsi, Struktur, dan Kaidah serta Langkah Penulisannya dalam Mata Pelajaran Bahasa Indonesia SMA/MA/SMK. 2014.

[9] A. W. Amalia, Syambasril, "No Title," J. Pendidik. dan Pembelajaran, vol. 9, no. 9, pp. $1-10,2015$.

[10] S. A. W. Sumiyati, "Pengaruh Konsep 3N "Niteni, Nirokke, Nambahi, " terhadap Prestasi Belajar Matematika Ditinjau dari Keaktifan Siswa Kelas X SMK," Proceeding Isbn, pp. 761-768, 2013.

[11] Harefa, Menulis Mengarang Bisa Gampang. Gramedia, Jakarta, 2002.

[12] B. S. Ahmad, "Peningkatan Keterampilan Menulis Cerita Pendek siswa Kelas VI SD Negeri Karangjati dengan Strategi 3M (Meniru, Mengolah, Mengembangkan)," J. Pendidik. Guru Sekol. Dasar, vol. 5, no. 2, pp. 95-102, 2016.

[13] Daryanto, Media Pembelajaran. Bandung Satu Nusa, 2015. 